Jurnal Ilmu dan Teknologi Kesehatan

Vol 8, No 1, September 2020,

ISSN: 2338-9095 (Print)

ISSN: 2338-9109 (online)

\title{
The Vital Lung Capacity of Employees with Risk Factors for Potential Exposure to Ammonia Gas
}

\author{
Ibrahim Edy Sapada ${ }^{1}$, Wita Asmalinda ${ }^{2}$ \\ ${ }^{1}$ STIK Siti Khadijah Palembang, Indonesia \\ ${ }^{2}$ Poltekkes Kemenkes Palembang, Indonesia \\ Email:wita_asmalinda@yahoo.co.id
}

\section{Article history}

Posted, April 6th, 2020

Reviewed, Sept 10th, 2020

Received, Sept 27th, 2020

\begin{abstract}
The fertilizer industry produces several pollutants such as ammonia gas, urea dust, smoke, particulates. Workers are exposed to air inhalation at work, entering the respiratory system, which is the main toxic entry point. The risk of workers being exposed to lung disease due to inhalation of dust/ smoke/ harmful gases in the work environment. It will increase if workers do not comply with protecting themselves from risk factors and potential accompanying factors such as smoking habits excessive body mass index. Lung ventilation is the entry and exit of air between the atmosphere and the pulmonary alveoli. This study aimed to determine the correlation between body mass index, smoking habits, and hemoglobin levels with vital lung capacity to P.T. Pupuk Sriwidjaja Palembang employees. The design of this study is a cross-section. The research was conducted at P.T. Pupuk Sriwidjaja for 30 days. The research sample was 78 employees of the ammonia unit. Data analysis found a significant correlation between vital lung capacity with body mass index (p-value $=0.009)$, and hemoglobin levels ( $p$-value $=0.039$ ). There was no significant correlation between smoking habits and vital lung capacity values ( $p$-value $=0.449)$. It can be concluded that body mass index, smoking habits, and hemoglobin levels correlate with vital lung capacity.
\end{abstract}

Keywords: Body mass index; smoking; hemoglobin; lung vital capacity

\begin{abstract}
ABSTRAK
Industri pupuk menghasilkan beberapa polutan seperti gas ammonia, debu urea, asap, partikulat. Pekerja terpajan melalui inhalasi udara di tempat kerja, masuk ke sistem pernapasan yang merupakan jalur masuk toksikan yang utama. Resiko pekerja terkena penyakit paru akibat terhirup debu/ asap/ gas berbahaya di lingkungan kerja akan bertambah jika pekerja tidak mematuhi cara melindungi diri dari faktor resiko dan faktor penyerta yang berpotensi seperti kebiasaan merokok, dan indeks massa tubuh berlebih. Ventilasi paru adalah masuk dan keluarnya udara antara atmosfir dan alveoli paru. Tujuan penelitian ini adalah untuk mengetahui korelasi antara indeks massa tubuh, kebiasaan merokok dan kadar haemoglobin dengan kapasitas vital paru karyawan PT. Pupuk Sriwidjaja Palembang. Desain penelitian ini adalah cross sectional. Penelitian dilaksanakan di PT. Pupuk Sriwidjaja selama 30 hari.
\end{abstract}


Sampel penelitian adalah karyawan unit ammonia berjumlah 78 orang. Analisis data didapatkan ada korelasi yang bermakna antara kapasitas vital paru dengan indeks massa tubuh $(p$ value $=0.009)$, dan kadar haemoglobin $(p$ value $=0.039)$, tidak ada korelasi yang bermakna antara kebiasaan merokok dengan nilai kapasitas vital paru ( $p$ value $=0.449$ ). Dapat disimpulkan bahwa indeks massa tubuh, kebiasaan merokok dan kadar hemoglobin berkorelasi dengan kapasitas vital paru.

Kata kunci: indeks massa tubuh; merokok; hemoglobin; kapasitas vital paru

\section{INTRODUCTION}

A polluting work environment, such as the fertilizer industry, can affect lung function. The fertilizer industry produces several pollutants, such as ammonia gas, urea dust, smoke, and particulates (Dwiputra, 2019; Thakkar, A., 2013). Ammonia gas is a gas that is colorless and has a powerful odor. Exposure to ammonia gas at a certain level disrupts lung function and sensitivity of the sense of smell (Dwirani, F., 2017). Lung disease that results from occupational hazard (hazardous material) exposure has a significant impact on workers' health (Jurniawidjaja, 2010). Workers are exposed by inhalation of air in the workplace into the respiratory system, which is the main route of entry for toxins, due to its wide surface contact with outside air, high blood flow, and very thin alveolar epithelium. The risk of workers getting lung disease due to inhalation of dust/ fumes/ hazardous gases in the work environment. It will increase if workers do not comply with ways to protect themselves from risk factors (Jurniawidjaja, 2010) and potential co-factors such as smoking (Oviera, A., 2016) and excess body mass index (Pinzon, R., 1999).

The American Lung Association divides lung diseases into two broad groups, namely pneumoconiosis caused by dust getting into the lungs, and hypersensitivity, such as asthma, caused by an overreaction to air pollutants. The most common pneumoconiosis experienced by workers is silicosis, a lung disease caused by inhaling silica dust. Some lung cancer cases and bronchitis cases are also classified as occupational lung diseases (Buchari, 2007). According to the European Respiratory Society, the prevalence of occupational lung disease is about $15 \%$ of men and $5 \%$ of women who have lung cancer, $17 \%$ of adult asthma cases, $15 \%-20 \%$ of chronic obstructive pulmonary disease (C.O.P.D.), and $10 \%-15 \%$ of cases of interstitial lung disease. In 2000 it was estimated that a total of 7,200 cases of pneumoconiosis were associated with exposure to asbestos, silica, and coal dust. The number of 
3 Jurnal Ilmu dan Teknologi Kesehatan, Vol. 8, Nomor 1, September 2020, hlm:1-13

occupational disease cases in Indonesia alone for 2011-2014 shows a decrease from 57,929 cases in 2011 to 40,696 cases in 2014. South Sumatra Province became the second largest in 2012 with 2,717 cases and decreased to 772 cases in 2013 (Kemenkes RI., 2019).

The vital lung capacity (CVP) is the amount of air that voluntary efforts can release after deep inspiration (Guyton and Hall, 2012). The lung's vital capacity is the sum of the tidal volume, the inspiratory reserve volume, and the inner expiratory reserve volume (Guyton and Hall, 2012; Bakhtiar, A., 2016). The lung's vital capacity reflects the change in the maximal volume of the lung, which is useful for confirming the picture of the lung's functional capacity. The vital capacity of the lungs can be measured using a pulmonary function test kit. The most basic test used is spirometry (Sherwood, 2014; Pellegrino. R., 2010; Smeltzer, SC., 2002). The measurement of vital lung capacity is the most massive air expelled volume after the deepest inspiration is capable of. There will be suction pressure during inspired breathing, which will affect the increase in lung volume and capacity (Bakhtiar, A., 2016). The value of vital capacity is influenced by age, gender, body weight (Pujiastuti, BE.,
2012; Zulfrianingrum, H., 2016), body position, respiratory muscle strength, lung, and chest cavity ability to expand (Bakhtiar, A., 2016) ). Decreasing hemoglobin levels can affect the mechanisms of oxygen and carbon dioxide transport in blood and body fluids to cells and vice versa (Bakhtiar, A., 2016). The fatigue factor affects the decrease in the blood muscles' ability to supply oxygen (Sapada, 2019). Workers who have maximum concentration resistance and cardiorespiratory resistance have normal levels (Sapada, 2019). The lungs' vital capacity is reduced if there are lung and heart disease, which causes lung congestion and weakness of the respiratory muscles (Hapsari, R., 2009).

According to Pinzon's study (1999), a decrease in the percentage of vital lung capacity in individuals with excess body mass index is suspected due to a decrease in elasticity and the ability to expand the chest wall and a decrease in the ability of the diaphragm to drop to its level. So that the intra-thoracal pressure will be less negative than average, according to research by Hapsari, R (2009), every cigarette puff can increase heart racing and blood pressure so that there is a lack of oxygen in the bloodstream. The presence of toxins found in cigarettes will inhibit 
gas exchange with the alveoli. It will reduce the number of functional alveoli that play a role in the respiration process, as a result of which there will be a decrease in lung function.

According to Anggraini's research, L (2019), the oxygen supply in smokers has decreased because hemoglobin binds more to carbon monoxide (200-300 times) than oxygen, thus inhibiting oxygen transport to body tissues. The primary function of hemoglobin is to bind oxygen. Hemoglobin in the blood allows it to carry 30-100 times the amount of oxygen to be transported in the form of dissolved oxygen in the blood plasma. If the hemoglobin level is below average, the amount of oxygen in the blood is also less. There has not been much research on the relationship between hemoglobin and lung vital capacity.

\section{P.T. Pupuk Sriwidjaja Palembang (Pusri)} is a company that was founded as a pioneer producer of urea fertilizer in Indonesia. Products manufactured by P.T. Sriwidjaja fertilizer in the form of liquid ammonia, urea fertilizer, and N.P.K. fertilizer (PT. Pusri, 2019). Ammonia unit employees of P.T. Pupuk Sriwidjaja Palembang is in a work environment exposed to high-risk ammonia concentrations. This study aimed to determine the correlation between body mass index, smoking habits, and hemoglobin levels with P.T. Pupuk Sriwidjaja Palembang employees' vital lung capacity. This study is different from previous studies. This study was adding a variable hemoglobin level, which has never existed in similar studies.

\section{METHOD}

This research is an analytic observational study with cross-sectional study design. This research was conducted at P.T. Pupuk Sriwidjaja Palembang for 30 days. The sample in this study were some employees of the ammonia unit of P.T. Pupuk Sriwidjaja Palembang that meets the inclusion and exclusion criteria. The number of samples is 78 people. The sampling method used was consecutive sampling. The research sample explains the objectives, procedures, and benefits and risks used in this study. After getting the sample agreement, then signed the informed consent to become respondents in this study. This study's variables were the independent variables, namely body mass index, smoking habits, and hemoglobin levels, while the dependent variable was the value of vital lung 
capacity. Blood sampling and examination of hemoglobin levels and lung vital capacity were carried out by health workers from the Ibnu Sina Clinic Palembang. The equipment and materials used to assess lung function use a pulmonary function measuring instrument, namely a spirometer that uses electrical energy, a mouthpiece, an alcohol swab, a tray, an oval bowl (nierbekken), a handscoon, a table, a chair, a trash can, and a chlorine solution. The procedure for data collection of vital lung capacity is to position the subject in the correct position, sit upright or stand, feet flat on the floor, and not cross.

The sample is asked to loosen tight clothing. If the clothing is too tight, it can provide a limited image on the spirometer (giving a lower volume than actual). The nose is covered with a hand or nose clip, performs a spirometry examination with a spirometer and mouthpiece. The sample is asked to breathe normally first, then takes a deep breath and exhales the maximum, records the results displayed on the spirometer screen, and includes vital capacity (V.C.). The procedure for checking hemoglobin is washing hands, attaching a lancet to the depaice pen, attaching a handscoon, bringing digital hemoglobin closer together, wiping the fingertips using an alcohol swab, waiting for it to dry, sticking the fingertips using a sharp pen, throwing the first blood, pressing the finger. Bring the steak to the peripheral blood until the blood is sucked in, wait until the hemoglobin value is displayed on the screen, read the hemoglobin test results, record the results and organize the tools and materials. Statistical analysis used for data processing in this study is to use the ChiSquare test. This test's feasibility has a requirement that the expected value is less than 5 to a maximum of $20 \%$ of the number of cells, so it is feasible to be tested with the Chi-Square test with a significance level of $\mathrm{p}<0.05$.

This research has received an ethical approval recommendation from the Palembang Health Polytechnic Research Ethics Commission Number. 008/DIRKOMITE ETIK/III/2020.

\section{RESULTS AND DISCUSSION}

This research was conducted for 30 days from January 2 to January 31, 2020, held at P.T. Pupuk Sriwidjaja Palembang, located at Jl. May Zen, Kalidoni, Kec. Kalidoni, Palembang City, South Sumatra 30118. P.T. Pupuk Sriwidjaja Palembang is a fertilizer industry producer in Indonesia which has five factories, namely Pusri I, Pusri II, Pusri III, Pusri IV, and Pusri IB. This research was conducted at 
Pusri III ammonia and urea units and obtained 78 respondents.

Univariate analysis was used to determine the description of age, length of work, body mass index (B.M.I.), smoking habits, hemoglobin levels, and vital lung capacity.

Table 1. Univariate analysis

\begin{tabular}{lcc}
\hline \multicolumn{1}{c}{ Variable } & n & \% \\
\hline Age (Year) & & \\
$26-35$ & 61 & 78.2 \\
$36-45$ & 15 & 19.2 \\
$46-55$ & 2 & 2.6 \\
\hline Body Mass Index & & \\
$\quad$ Less & 2 & 2.6 \\
Normal & 32 & 41 \\
More & 10 & 12.8 \\
Obesity & 34 & 43.6 \\
\hline Long of work (year) & & \\
New (5-10 years) & 46 & 59 \\
Long (>10 years) & 32 & 41 \\
\hline Smoking Status & & \\
Yes & 17 & 21.8 \\
No & 61 & 78.2 \\
\hline Hemoglobin Level (gr/dL) & & \\
Low & 18 & 23.1 \\
Normal & 34 & 43.6 \\
High & 26 & 33.3 \\
\hline Lung Vital Capacity (ml) & & \\
Abnormal (<4500) & 35 & 44.9 \\
Normal ( $\geq 4500)$ & 43 & 55.1 \\
\hline
\end{tabular}

Table 1 shows that most respondents' age range was 26-35 years, which are 61 respondents $(78.2 \%)$. The most body mass index categories of respondents are the B.M.I. The obesity group is 34 respondents (43.6\%). It was found that the longest working category was in the new old working group (59.0\%). Most respondent's smoking status category is no smoking status group (78.2\%). The lowest respondent's hemoglobin level was 10.3 gram/ dL, and the highest hemoglobin level was 17.7 gram / dL. The hemoglobin levels is categorized into 3 groups: low hemoglobin levels (<12 grams/ dL), normal (12 gram dL-15 gram/ dL) and 
7 Jurnal Ilmu dan Teknologi Kesehatan, Vol. 8, Nomor 1, September 2020, hlm:1-13

high hemoglobin levels1 (> 15 gram/ dL). It was found that the group with low hemoglobin levels were 18 people $(23.1 \%)$.

The results showed that the vital capacity value of the lungs varied from $3355 \mathrm{ml}$ to $4925 \mathrm{ml}$. The description of vital lung capacity values is categorized into two groups, category abnormal lung vital capacity $(<4500 \mathrm{ml})$ and normal lung vital capacity ( $\geq 4500 \mathrm{ml})$. It was found that the normal vital lung capacity group was 43 people $(55.1 \%)$ more than the abnormal vital lung capacity group (44.9\%).

Table 2. Correlation of Body Mass Index with Lung Vital Capacity

\begin{tabular}{|c|c|c|c|c|c|c|}
\hline \multirow[t]{3}{*}{ Body Mass Index } & \multicolumn{4}{|c|}{ Lung Vital Capacity } & \multirow[t]{3}{*}{ Total } & \multirow[t]{3}{*}{ p-value } \\
\hline & \multicolumn{2}{|c|}{ Abnormal } & \multicolumn{2}{|c|}{ Normal } & & \\
\hline & $\mathbf{n}$ & $\%$ & $\mathbf{n}$ & $\%$ & & \\
\hline Low/Normal & 10 & 12.8 & 24 & 30.8 & 34 & \\
\hline Over/Obesity & 25 & 32.1 & 19 & 24.3 & 44 & 0.009 \\
\hline Total & 35 & 44.9 & 43 & 55.1 & 78 & \\
\hline
\end{tabular}

Table 2 shows the statistical analysis of the chi-square test, the p-value $=0.009(\mathrm{p}$ $<0.05)$. It means that there is a correlation between body mass index and the value of vital lung capacity. The odd ratio value 8.989, which means that the sample with a body mass index is over/ obesity, has a risk of decreased lung capacity 8.989 times compared to samples with a body mass index low/ normal. This study's results are not in line with Oviera's research (2016), which states that there is no relationship between nutritional status and vital lung capacity in wood processing industry workers.
Excess body mass index and obesity tend to decrease the value of vital lung capacity due to the disruption of the lung walls, which affects lung ventilation (Pinzon, 1999). Increasing the amount of fat in the chest and abdominal walls are thought to affect the chest and diaphragm's mechanical properties. According to Citizen, RK, an increase in the amount of mass activity causes compliance with the chest and abdominal walls and decreases the residual volume and lung capacity. (2015). This accumulation of fat causes a disturbance in elasticity so that the respiratory muscles work hard to overcome excessive elastic recoil. The primary function of pulmonary ventilation 
disorders is a restriction (restriction syndrome), which is a disruption in lung development, obstructive (blockage syndrome), which is obstruction of airflow due to obstruction or narrowing of the airways (Pellegrino, R., 2010). The process of respiration to run smoothly requires a useful function of the lung tissue's respiratory muscles and elasticity (Pellegrino, R., 2010). Air flows following a decrease in pressure gradient, intraalveolar pressure must be less than atmospheric pressure for air to flow into the lungs during inspiration and must be greater than atmospheric air pressure to flow out of the lungs during expiration. The intra-alveolar pressure can be changed by changing the lung volume according to Boyle's law. Boyle's law states that the pressure exerted by a gas is inversely proportional to the volume of the gas at a constant temperature. As the volume of gas increases, the gas's pressure decreases proportionately, and vice versa. Changes in lung volume are caused indirectly by the activity of the respiratory muscles (Pellegrino, R., 2010)

The respiratory muscles that carry out the breathing motion do not act directly on the lungs to change their volume. However, it changes the volume of the thoracic cavity.
It causes a similar change in lung volume because the thoracic wall and lung wall are associated through the intrapleural fluid and the transmural pressure gradient (Pelegrino, R., 2010). The vital capacity of the lungs is the ability of the lungs to accommodate oxygen optimally. The amount of oxygen that can be put into the lungs is determined by the ability to expand and collapse the respiratory system (Kenney, 2012; Hapsari, R., 2009). The level of lung capacity is thought to have a substantial contribution and relationship to physical health. The higher the lung capacity a person has, the more oxygen can be used for the respiratory system. A person who has an adequate level of physical fitness will carry out daily tasks effectively in a relatively long time without experiencing fatigue (Hapsari, R., 2009).

Oxygen is carried to body tissues through two mechanisms: it is physically dissolved in plasma and chemically bound to hemoglobin as oxyhemoglobin ( $\mathrm{HbO} 2)$. Oxygen is needed by body cells as a source of energy. In the respiratory system, oxygen enters the lungs and oxidizes the nutrients that enter the digestive system (Pinugroho, B., 2017). 
9 Jurnal Ilmu dan Teknologi Kesehatan, Vol. 8, Nomor 1, September 2020, hlm:1-13

Table 3. Correlation of Smoking Habit with Lung Vital Capacity

\begin{tabular}{|c|c|c|c|c|c|c|}
\hline \multirow{3}{*}{ Smoking Habit } & \multicolumn{4}{|c|}{ Lung Vital Capacity } & \multirow[t]{3}{*}{ Total } & \multirow{3}{*}{ p-value } \\
\hline & \multicolumn{2}{|c|}{ Abnormal } & \multicolumn{2}{|c|}{ Normal } & & \\
\hline & $\mathbf{n}$ & $\%$ & $\mathbf{n}$ & $\%$ & & \\
\hline Yes, smoking & 9 & 11.6 & 8 & 10.2 & 17 & \\
\hline No, smoking & 26 & 33.3 & 35 & 44.9 & 61 & 0.449 \\
\hline Total & 35 & 44.9 & 43 & 55.1 & 78 & \\
\hline
\end{tabular}

Table 3 shows that the results of statistical analysis obtained p-value $=0.449(\mathrm{p}>$ 0.05). There is no significant correlation between smoking habits and the value of vital lung capacity. The odd ratio value 4.456 means that the sample with a smoking habit has a risk of decreasing lung capacity by 4.456 times compared to the sample who does not smoke. The results of this study are not in line with the research of Oviera, A (2016), Nisa, K. (2015), and Abdulrahman, W.F. (2002) states that there is a relationship between smoking habits and vital lung capacity in wood processing industry workers. A polluted work environment causes pulmonary obstruction. Obstructive pulmonary dysfunction occurs due to the narrowing of the trachea and bronchi. The narrowing can be localized as well as in the expanding lung (Oviera, A., 2016).

Histological changes in small airways occur after two years of smoking (Aunillah, 2015). According to Kurniawidjaja, LM., (2010), smoking habits were assessed using the Brinkman index, which is calculated based on the multiplication of the number of cigarettes smoked per day with the length of smoking in a year, light smokers: 1-200, moderate smokers 201-600 and heavy smokers> 600. The number of samples who smoked in this study amounted to 17 people $(20.8 \%)$ with the category of light smokers, although included in the category of light smokers, workers should stop risk factors because cigarette smoke can cause local damage to the respiratory tract, such as loss of ciliary function. Cilia function as a deterrent for foreign objects so that foreign objects and other pollutants will not quickly enter the lungs. This decrease in ciliary function increases the risk of pulmonary function disorders because dust and pollutants can quickly enter the lungs. This theory clearly states that cigarette smoke can decrease lung function so that pulmonary function disorders are experienced not only in active smokers and ex-smokers but also by passive smokers. Smoking habits and will accelerate the decline in lung function (Barakati, RV., 2015). Cigarettes contain 
more than 4000 chemicals that are exposed through cigarette smoke. The lungs become a place for the exchange of substances contained in cigarettes.
Cigarettes cause an abnormal lung inflammatory response to toxic particles from cigarettes (Sidikin, M., 2001).

Table 4. Correlation of Hemoglobin Level with Lung Vital Capacity

\begin{tabular}{lccccccc}
\hline \multirow{2}{*}{ Hemoglobin Levels } & \multicolumn{4}{c}{ Lung Vital Capacity } & & Total & p-value \\
\cline { 2 - 5 } & \multicolumn{2}{c}{ Abnormal } & \multicolumn{2}{c}{ Normal } & & \\
\cline { 2 - 5 } & $\mathbf{n}$ & $\mathbf{\%}$ & $\mathbf{n}$ & $\mathbf{\%}$ & & \\
\hline Rendah & 4 & 5.1 & 14 & 18 & 18 & \multirow{2}{*}{0.039} \\
Normal & 20 & 25.7 & 14 & 18 & 34 & \\
Tinggi & 11 & 14.1 & 15 & 19.1 & 26 & \\
\hline Total & 35 & 44.9 & 43 & 55.1 & 78 & \\
\hline
\end{tabular}

Table 4 shows the statistical analysis results show that the $\mathrm{p}$-value $=0.039(\mathrm{p}$ $<0.05)$. There is a correlation between hemoglobin levels and the value of vital lung capacity. This study's results are not in line with the research of Pujiastuti, BE (2012), that there is no influence of hemoglobin levels with the vital capacity of the lungs in pregnant women. In the process of external respiration, when the inspired air reaches the alveoli, it makes direct contact with the blood around the capillary network, oxygen diffuses into the venous blood until the pressure is equal. In internal respiration, oxygen diffused into the blood is then carried into the hemoglobin called oxyhemoglobin to the tissues (Bakhtiar, A., 2016). The higher the lung volume, the easier the hemoglobin will bind oxygen. Normal hemoglobin levels will determine how much oxygen can bind.

The clean surface of the alveoli in the lungs determines the diffusion of the gas. In people who have anemia, oxygen transport to the tissues will be reduced and result in tissue hypoxia. This hypoxic state will decrease the activity of the respiratory muscles. As a result, the lungs become heavier to meet their oxygen needs; this is directly proportional to the increased value of vital lung capacity (Bakhtiar, A., 2016). This hypoxic state will also suppress the respiratory center, causing the chemoreceptors to increase, and eventually, respiration increases. Hemoglobin level has a negative effect on 
the vital capacity of the lung. The lower the hemoglobin level, the higher the value of the lung's vital capacity (Zulfaningrum, H., 2016). The heme in hemoglobin is a circular compound called porphyrin, the center of which is occupied by ferrous metal (Sidikin, M., 2001). An iron that is in the hemoglobin molecule is essential for carrying out the function of binding and releasing oxygen. Although not directly binds to the molecule oxygen, globin is a crucial part of hemoglobin. It helps determine the iron atom's binding power in these molecules (Sidikin, M., 2001).

Occupational health is necessary in the world of work - control using risk management. The concept of risk management is to manage risk so that the risk is lost or minimized at a level that is not dangerous. Primary prevention aims to prevent workers from being exposed to disease-causing agents, in the form of particles/ vapors and gases in the work environment, by increasing workers' knowledge of risk factors and increasing compliance with personal protective equipment. Secondary prevention uses early detection of occupational diseases and handling cases as soon as possible so that the disease does not become severe.
Tertiary prevention aims to protect workers who are already affected by lung disease so they can return to work and not become disabled (Kurniawidjaja. LM., 2010).

\section{CONCLUSION}

Based on the discussion analysis results, it can be concluded that there is a significant correlation between body mass index and hemoglobin levels with the value of vital lung capacity. There is no significant correlation between smoking habits and vital lung capacity. It is suggested to do further research on the molecular level of the TNF- $\alpha$ parameter.

\section{REFERENCE}

Abdulrahman, W.F. 2002. Efect of Smoking on peak expiratory flow rate in Tikrit University. Tikrit Medical Journal, 17(1):11-18.

American Lung Association. 2017. Lung Function Test. (https://www.lung .org/lung-health and-diseases/lung procedures-and-tests/lung-functiontests.html) accessed 31 Juli 2019.

Anggraini, L., \& Wirjadmadi, R.M. 2019. Hemoglobin Status, Smoking Habits, and Cardiorespiratory Endurance (VO2Max) in Basketball Student Activity Unit Athletes. Indonesian Nutrition Media, 14(1): 27-34.

Aunillah, K., \& Ardan, Y. 2015. Relationship between Dust Exposure 
and Duration of Exposure with Pulmonary Disorders of Power Plant Overhaul Workers. The Indonesian Journal of Occupational Safety and Health, 4(2): 155-166.

Bakhtiar, A \& Amran, W.S. 2016. Static Pulmonary Physiology. Journal of Respiration, 2 (3): 91-98.

Barakati, RV, Lintong, F, \& Moningka, MEW. 2015. Comparison of Forced Vital Capacity of Smoker and NonSmoker Students at the Faculty of Medicine, University of Sam Ratulangi Manado. Journal of $e$ Biomedics (eBM), 3(1): 350-354.

Buchari. 2007. Occupational Diseases and Work-Related Diseases. Medan: University of North Sumatra Repository.

Dwiputra, and Edmundo C. 2019. The Factors Affecting Lung Function in Stone Breaking Workers in Bandar Lampung City. Tesis. Lampung: Fakultas Kedokteran Universitas Lampung.

Dwirani, F. Ammonic Gas Pollution and Its Impact on Workers and the Surrounding Community: A case study at P.T. Pupuk Kujang Cikampek, West Java. Universitas Indonesia Library $>\quad$ UI-Thesis (Membership). lib.ac.id> file> abstract-93110, accessed on 12 November 2019.

European Respiratory Society. European Lung White Book: Occupational Lung Disease Chapter 24. (https://www.erswhitebook.org/chapte rs/occupational-lung-diseases), accessed on 1 Agustus 2019.
Guyton AC and Hall JE. 2012. Textbook of Medical Physiology. Edisi 9. Jakarta: E.G.C.

Hapsari, R. 2009. The Effect of Gambing Dust Exposure on Lung Vital Capacity in Gambing Workers at UD Telaga Agung Blora, Central Java. Tesis. Semarang: aFakultas Kesehatan Masyarakat UNNES.

Juarfianti, Engka, J.N.A., and Supit, S. 2015. Vital Lung Capacity in the Upland Population of Rurukan Tomohon Village. Journal of $e$ Biomedics (eBm), 3(1): 430-434.

Ministry of Health of the Republic of Indonesia (Kemenkes RI). 2019. Occupational Health Situation. InfoDATIN: Center for Data and Information of the Ministry of Health of the Republic of Indonesia, accessed on 12 September 2019.

Kenney, Wilmore \& Costill, 2012. Physiology of Sport and Exercise Edisi-6. Medicine and Health Human Kinetics.

Kurniawidjaja, LM. 2010. Respiration Health Protection Program in the Workplace Risk Management of Occupational Diseases. Indonesian Journal of Respirology, 30(4): 217229.

Nisa, K. Sidharti, L \& Adityo, M.F. 2015. The Effect of Smoking Habits on Lung Function in Male Employees in the Rectorate Building, University of Lampung. Journal of Health Unila, 5(8): 38-42.

Oviera, A., Jayanti, S., \& Suroto. 2016. Factors Related to Vital Lung Capacity in Wood Processing Industry 
Workers at P.T. X Jepara. Journal of Public Health (e-journal), 4(1): 267276.

Pellegrino, R., Antonelli, A., \& Mondino, M. 2010. Bronchodilator Testing: an Endless Story.European Respiratory Journal, 35(5): 952-954.

Pinugroho, B. Setyo \& Kusumawati, Yuli. 2017. The Relationship of Age, Duration of Dust Exposure, Use of P.P.E., Smoking Habit with Impaired Lung Function in Mabel Workers in Kec. Kalijambe Sragen. Journal of Health, 10(2): 1979-7621.

Pinzon, R. 1999. Relationship between Body Mass Index and Vital Capacity of Lungs for Young Age Groups. Bulletin of Health Research, 26 (1): 15-19.

PT. Pupuk Sriwidjaja Palembang. Fertilizer Sriwidjaja Palembang. (http: //pusri. or.id), accessed August 2, 2019.

Pujiastuti, BE., Sulastri, Zulaicha. 2012. Analysis of Factors Affecting Vital Lung Capacity in Pregnant Women at R.B. Sri Lumintu Jajar Laweyan Surakarta. Tesis. Surakarta: Faculty of Health Sciences, Muhaamdiyah University Surakarta.

Sapada, IE., \& Asmalinda, W. 2019. Pengaruh Wet Cupping terhadap Peningkatan Kadar hemoglobin. Jurnal Kesehatan Poltekkes Tanjung Karang, $\quad 10(2)$ : 175-180. DOI: http://dx.doi.org/10.26630/jk.v10i2.12 05.

Sherwood, Lauralee. 2014. Physiology of Humans from Cells to Systems. 8th Edition. Jakarta: E.G.C.

Sidikin, M. 2001. Blood Biochemistry. Jakarta: Widya Medika.

Smeltzer, S.C and Bare, B.G. 2002. Textbook of Medical-Surgical Nursing (Brunner \& Suddarth) Edition 8 Vol. 1. Jakarta: E.G.C.

Thakkar, A. 2013. Analysis of Air Pollution Parameters of Fertilizer Industries Specially Reference to G.S.F.C. Vadodara, Gujarat. International Journal of Theoretical \& Applied Sciences, 5(2): 109-113

Warganegara, RK. 2015. The Comparation of Lung Vital capacity in Various Sports Athlete. Jurnal Majority, 4(2); 96-103.

Zulfrianingrum, H. 2016. Relationship between Hemoglobin Levels and Vital Lung Capacity with Cardiorespiratory Endurance of Students Participating in Basketball Extra-curricular at S.M.P. Negeri I Jetis, Bantul Regency. Tesis. Yogyakarta: Department of Sports Education, Universitas Negeri Yogyakarta. 